\title{
VARIASI SUHU PENGERINGAN CANGKANG TELUR AYAM PADA PEMBUATAN PUPUK ORGANIK
}

\author{
Utari Lestari Dewi ${ }^{1}$, Hernawati ${ }^{2}$, Nurul Fuadi ${ }^{3}$ \\ ${ }^{1}$ Mahasiswa Jurusan Fisika \\ Fakultas Sains dan Teknologi UIN Alauddin Makassar \\ Jl. Sultan Alauddin No. 63, Gowa, Sulawesi Selatan. 92113 \\ E-mail: hutarilestari82@gmail.com \\ ${ }^{2,3}$ Tenaga Pengajar Jurusan Fisika \\ Fakultas Sains dan Teknologi UIN Alauddin Makassar \\ J1. Sultan Alauddin No. 63, Gowa, Sulawesi Selatan. 92113
}

\begin{abstract}
Abstrak: Penelitian ini bertujuan untuk mengetahui pengaruh variasi suhu pengeringan cangkang telur terhadap kualitas pupuk organik. Dengan menggunakan dua metode pengujian, yang pertama pengujian menggunakan Atomic Absorption Spectrophotometry (AAS) untuk mengetahui kadar kalsium pada cangkang telur yang telah dikeringkan pada suhu yang bervariasi, yang kedua pengujian pupuk pada tanaman. Hasil yang diperoleh adalah dengan pengujian kadar kalsium dan pengujian pada tanaman menunjukkan bahwa pengeringan kulit telur pada suhu rendah tidak menurunkan nilai kadar kalsium yang terdapat pada kulit telur, begitu pula sebaliknya pengeringan dengan suhu tinggi dapat menurunkan nilai kadar kalsium kulit telur. Pada pengujian pertumbuhan tanaman meliputi tinggi batang, jumlah batang dan daun tanaman yang memiliki pertumbuhan baik adalah tanaman yang dipupuk dengan cangkang telur yang dikeringkan pada suhu $37^{\circ} \mathrm{C}$ dan $50^{\circ} \mathrm{C}$ dan hasil uji kadar kalsium menunjukkan pada suhu $37^{\circ} \mathrm{C}$ sebanyak $1,32 \%$, pada $50^{\circ} \mathrm{C}$ sebanyak $1,06 \%$, suhu $100^{\circ} \mathrm{C}$ sebanyak $2,21 \%$ dan suhu $150^{\circ} \mathrm{C}$ sebanyak $0,80 \%$. Namun dari hasil pengujian kandungan kalsium cangkang telur pada suhu $100^{\circ} \mathrm{C}$ nilai kandungan kalsiumnya lebih tinggi, karena kemungkinan pada suhu $100^{\circ} \mathrm{C}$ merupakan suhu yang baik untuk digunakan dalam proses pengeringan, pada suhu ini kandungan senyawa lain dapat terurai sempurna dan kandungan kalsium meningkat.
\end{abstract}

Kata Kunci: cangkang telur, pupuk organik, spektrofotometri, suhu

\section{PENDAHULUAN}

$\lceil$ m ndonesia merupakan salah satu negara yang hampir semua penduduknya sangat menyukai telur, yang dijadikan sebagai makanan pokok baik itu telur ayam, bebek maupun telur puyuh. Banyaknya telur yang dikonsumsi di semua kalangan baik itu anak-anak maupun orang tua, maka banyak pula limbah cangkang telur yang dibuang begitu saja di lingkungan sekitar. Cangkang telur merupakan limbah yang dapat diolah kembali sehingga, memiliki nilai yang cukup tinggi untuk dipasarkan. Meskipun belum cukup banyak yang mengetahui bahwa cangkang telur ini dapat dimanfaatkan kembali seperti dijadikan sebagai pupuk untuk berbagai jenis tanaman. Limbah cangkang telur yang dibuang begitu saja di sekitar lingkungan bisa menimbulkan lingkungan yang tercemar dan kurang sehat. Sehingga dapat membahayakan kelangsungan hidup bagi makhluk hidup lainnya. 
Cangkang telur memiliki beberapa struktur lapisan, lapisan pertama berupa kutikula ialah berupa protein transparan yang menyelimuti permukaan kulit telur, dan lapisan kedua merupakan lapisan busa yang komponen terbanyak pada bagian cangkang telur, terdapat protein, kalsium karbonat, kalsium fosfat, magnesium karbonat dan magnesium fosfat yang merupakan lapisan kapur. Lapisan ketiga yaitu mamilary merupakan lapisan yang paling tipis dan terdiri dari anyaman protein serta mineral, lapisan keempat merupakan lapisan paling dalam membran (Faisol, 2008).

Tabel 1. Komposisi nutrisi cangkang telur

\begin{tabular}{lc}
\hline Nutrisi & Cangkang Telur $(\%$ berat $)$ \\
\hline Air & $29-35$ \\
Protein & $1,4-4$ \\
Lemak Murni & $0,10-020$ \\
Abu & $9,9-91,1$ \\
Kalsium & $35,1-36,4$ \\
Kalsium Karbonat $\left(\mathrm{CaCO}_{3}\right)$ & 90,9 \\
Fosfor & 0,12 \\
Sodium & $0,15-0,17$ \\
Magnesium & $0,37-0,40$ \\
Pottasium & $0,10-0,13$ \\
Sulfur & $0,90-0,19$ \\
Alanin & 0,45 \\
Arginin & $0,56-0,57$ \\
\hline Sumber:
\end{tabular}

Sumber: Zulti, 2008

Pupuk merupakan unsur hara yang sangat diperlukan pada tumbuhan dalam yang dapat membantu pertumbuhan dan perkembangan pada tanaman. Pupuk berdasarkan bentuknya terdiri dari dua jenis yaitu pupuk cair dan pupuk padat. Pupuk organik memiliki kandungan utama berupa unsur N, P, dan K. Pupuk organik merupakan pupuk yang terbuat dari modul makhluk hidup, semacam kotoran hewan, serta pelapukan pada tumbuhan. Pupuk organik dapat membentuk padatan ataupun cair yang digunakan untuk pertumbuhan tanaman. Pupuk ini berfungsi pada perbaikan sifat fisik, biologi serta sifat kimia pada tanaman. Unsur hara yang terdapat pada pupuk organik dapat meningkatkan kualitas tanaman serta dapat melindungi tanaman dan menetralkan racun pada tanaman (Nurhidayati et al., 2008).

Pengeringan (drying) ialah proses perpindahan panas serta uap air, secara simultan membutuhkan energi panas sehingga dapat menguapkan kandungan air yang dipindahkan dari permukaan bahan yang dikeringkan oleh media pengeringan yang umumnya berbentuk panas. Bahan yang dikeringkan berkontak secara langsung dengan panas dari gas (udara), panas akan dipindahkan dari udara panas ke bahan yang akan dikeringkan. Tujuan dari pengeringan ini ialah mendapatkan hasil produk yang lebih baik misalnya dalam bentuk fisik (berupa bubuk atau butiran) serta warna, rasa dan tekstur bahan yang diinginkan (Harrison, 2000).

Spektrofotometri merupakan alat yang dapat digunakan untuk menganalisis kandungan dalam bahan, dengan melalui proses penyerapan energi radiasi pada atomatom yang berada di tingkat tenaga dasar. Proses penyerapan yang menyebabkan tereksitasinya suatu elektron dalam kulit atom ke tingkat yang lebih tinggi. Prinsip kerja alat ini dengan cara penguapan larutan pada sampel, dan logam yang terkandung di dalamnya dapat berubah menjadi atom bebas. Atom yang mengabsorbsi radiasi dari sumber cahaya lampu katoda yang mengandung unsur yang akan ditentukan (Gholib, 2007). 
Kacang tanah (Arachis hypogaea L.) merupakan tanaman polong-polongan atau legum yang dibudidayakan serta menjadi tanaman jenis kacang-kacangan yang terpenting. Awalnya tanaman ini berasal dari benua Amerika yang kemudian berkembang pesat di Indonesia dan menjadi salah satu jenis tanaman yang banyak diminati oleh masyarakat.

Berdasarkan uraian di atas, banyaknya pemanfaatan limbah cangkang telur salah satunya ialah pemanfaatan limbah cangkang telur yang diolah menjadi pupuk organik yang mengandung banyak kalsium sehingga dapat bermanfaat dan dapat membantu proses pertumbuhan tanaman terutama tanaman kacang tanah. Dengan ini maka dilakukan sebuah penelitian untuk mengetahui pengaruh variasi suhu pengeringan pada cangkang telur ayam terhadap kualitas pupuk organik.

\section{METODE PENELITIAN}

Peralatan yang digunakan adalah blender, ayakan 70 mesh, wadah (baskom), alat tulis, oven memmert, gelas ukur, corong, labu takar, pipet tetes, mistar, kamera, neraca digital, spektrofotometri (SSA), dan polibag. Bahan yang digunakan berupa cangkang telur ayam ras, bibit kacang tanah, aquabides, asam nitrat $\left(\mathrm{HNO}^{3}\right)$, asam perklorat $\left(\mathrm{HClO}^{4}\right)$, kertas saring, dan batu didih.

Prosedur kerja pada penelitian ini ada 3 tahap yaitu pertama pembuatan pupuk cangkang telur ayam, dengan cara menyiapkan limbah cangkang telur, kemudian dicuci bersih dengan air yang mengalir, setelah itu disimpan atau dikeringkan di tempat yang terbuka, selanjutnya blender cangkang telur sampai halus menggunakan blender, kemudian cangkang telur dioven dengan variasi suhu yang berbeda $\left(37^{\circ} \mathrm{C}, 50^{\circ} \mathrm{C}, 100^{\circ} \mathrm{C}\right.$, dan $150^{\circ} \mathrm{C}$ ) dengan waktu masing-masing suhu selama 120 menit, setelah dioven cangkang telur diayak menggunakan ayakan 70 mesh.

Tahap kedua proses pengujian kadar kalsium pada cangkang telur ayam dengan menggunakan alat spektrofotometri serapan atom (SSA), langkah pertama serbuk cangkang telur yang sudah dihaluskan ditimbang sebanyak $1 \mathrm{~g}$, dan memasukkannya ke dalam gelas ukur, kemudian tambahkan aquabides $50 \mathrm{ml}$ dan asam nitrat sebanyak $5 \mathrm{ml}$, kemudian tambahkan batu didih ke dalam larutan asam nitrat panaskan sampai mendidih, setelah itu didinginkan kembali, tambahkan asam perklorat sebanyak $1 \mathrm{ml}$, kemudian dipanaskan lagi sampai menghasilkan uap putih, lalu didinginkan kembali, kemudian larutan yang telah mendidih disaring ke dalam labu ukur dengan bantuan corong, larutan standar dibuat dengan konsentrasi 0,5; 1,0; 2,0 dan 5,0 ppm. Caranya larutan induk 1.000 ppm dipipet masing-masing 10, 25, 40, dan $55 \mathrm{ml}$ ke dalam labu takar untuk mengencerkan larutan sampai tanda batas dengan menggunakan aquabides, dan absorbansi diukur dengan menggunakan alat spektrofotometri, dengan mencatat hasil pengujian.

Tahapan ketiga, menyiapkan pupuk cangkang telur dengan variasi suhu yang berbeda-beda, kemudian menyiapkan 5 buah polibag dengan memberi label agar lebih mudah mengamati pertumbuhan dengan suhu yang berbeda, selanjutnya menanam bibit kacang tanah yang telah direndam ke dalam pot/polibag dengan tanah, memupuk tanaman dengan pupuk cangkang telur sebanyak 10 gram tiap tanaman, pemberian pupuk dilakukan interval waktu 4 hari sekali pemupukan selama proses penanaman.

\section{HASIL DAN PEMBAHASAN}

Penelitian ini dilakukan selama 31 hari dengan pengujian kualitas pupuk cangkang telur ayam dengan pengeringan bervariasi. Parameter yang diukur berupa tinggi batang, lebar daun dan jumlah tangkai. Selama pengujian tanaman diberi pupuk organik cangkang telur ayam sebanyak 10 gram dengan interval waktu sekali dalam sepekan. 
Table 2. Hasil pengujian kadar kalsium pada cangkang telur ayam

\begin{tabular}{cccc}
\hline No & Sampel & Variasi Suhu $\left({ }^{\circ} \mathrm{C}\right)$ & Kadar Kalsium $(\boldsymbol{\%})$ \\
\hline 1 & $\mathrm{~A}$ & 37 & 1,32 \\
2 & $\mathrm{~B}$ & 50 & 1,06 \\
3 & $\mathrm{C}$ & 100 & 2,21 \\
4 & $\mathrm{D}$ & 150 & 0,08 \\
\hline
\end{tabular}

Proses pengeringan yang bertujuan untuk menghilangkan kadar air yang berlebihan pada bahan, namun menggunakan suhu pengeringan yang tinggi dan waktu pengeringan yang lama sangat memengaruhi kualitas bahan tersebut. Namun pada hasil pengujian nilai kadar kalsium yang tertinggi pada suhu $100^{\circ} \mathrm{C}$ hal ini disebabkan kemungkinan pada suhu $100^{\circ} \mathrm{C}$ merupakan suhu yang terbaik dalam proses pengeringan cangkang telur, kandungan senyawa lainnya pada cangkang telur ini dapat terurai dengan baik, dan kandungan kalsium dapat meningkat.

Adapun data hasil pengukuran nilai konsentrasi yang digunakan dalam pengujian dengan nilai absorbansi tiap sampel ditunjukkan pada Tabel 3.

Tabel 3. Hubungan nilai konsentrasi dengan absorbansi

\begin{tabular}{cccc}
\hline No & Variasi Suhu $\left({ }^{\circ} \mathbf{C}\right)$ & Konsentrasi $(\mathbf{p p m})$ & Absorbansi (A) \\
\hline 1 & 37 & $0,5 \mathrm{ppm}$ & 0,0056 \\
2 & 50 & $1,0 \mathrm{ppm}$ & 0,0118 \\
3 & 100 & $2,0 \mathrm{ppm}$ & 0,0193 \\
4 & 150 & $5,0 \mathrm{ppm}$ & 0,0289 \\
\hline
\end{tabular}

Pada Tabel 3 dapat diperoleh sebuah grafik hubungan antara nilai absorbansi sampel dengan variasi nilai konsentrasi pada pengujian kadar kalsium yang ditunjukkan pada Gambar 1.

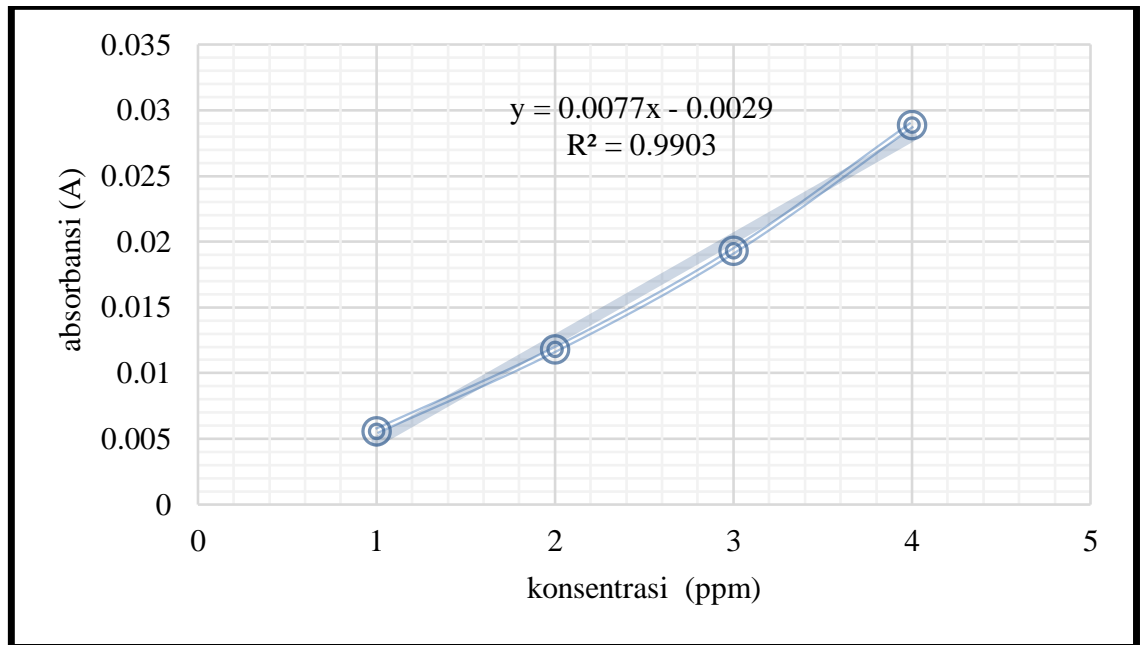

Gambar 1. Grafik hubungan nilai konsentrasi larutan dan absorbansi

Grafik pada Gambar 1 yaitu terkait hubungan antara nilai konsentrasi dengan daya absorbansi suatu larutan adalah berbanding lurus, artinya semakin tinggi nilai konsentrasi suatu senyawa dalam larutan, makin banyak pula sinar yang diserap. Hal ini terlihat pada grafik dengan nilai intercept $(\mathrm{a})=0,0077$ dan nilai slope $(\mathrm{b})=0,003$ dengan nilai korelasi $\left(\mathrm{R}^{2}\right)=0,9903$. Nilai korelasi yang didapatkan sebesar 0,9903 dapat dikatakan bahwa nilai korelasi tersebut sangat baik karena mendekati nilai 1. Dalam metode spektrofotometri ini larutan sampel dapat menyerap radiasi elektromagnetik dari sumber dan jumlah yang diserap bergantung pada tingginya nilai konsentrasi. 
Hasil pengamatan berupa pertumbuhan panjang batang kacang tanah ditunjukkan pada Tabel 4.

Tabel 4. Hasil pengamatan pertumbuhan panjang batang pada kacang tanah

\begin{tabular}{ccccccc}
\hline \multirow{2}{*}{ No } & \multirow{2}{*}{$\begin{array}{c}\text { Umur Tanaman } \\
\text { (Hari) }\end{array}$} & A & B & C & D & Tanpa Pupuk \\
\cline { 2 - 6 } & 11 & 10 & 11 & 14 & 14 & 16 \\
1 & 15 & 15 & 16,5 & 19 & 19 & 20,5 \\
2 & 19 & 23 & 21,5 & 22 & 22 & 22 \\
3 & 23 & 27 & 28 & 26,5 & 26,5 & 23,5 \\
4 & 27 & 32 & 30,5 & 30,5 & 28,5 & 25,5 \\
5 & 31 & 35 & 34 & 33,5 & 31,5 & 27,5 \\
6 & & 35 &
\end{tabular}

Keterangan: $\mathrm{A}=$ Suhu $37^{\circ} \mathrm{C} ; \mathrm{B}=\operatorname{Suhu} 50^{\circ} \mathrm{C} ; \mathrm{C}=100^{\circ} \mathrm{C}$; dan $\mathrm{D}=$ Suhu $150^{\circ} \mathrm{C}$

Tabel 4 merupakan hasil pengukuran tanaman selama 31 hari dalam proses penanaman. Dapat dilihat bahwa pertumbuhan panjang batang tanaman kacang yang menggunakan suhu rendah $37^{\circ} \mathrm{C}, 50^{\circ} \mathrm{C}$ dan suhu $100^{\circ} \mathrm{C}$ lebih cepat proses pertumbuhan atau pertambahan panjang pada batang daripada pertumbuhan dengan suhu tinggi dan tanpa pemberian pupuk.

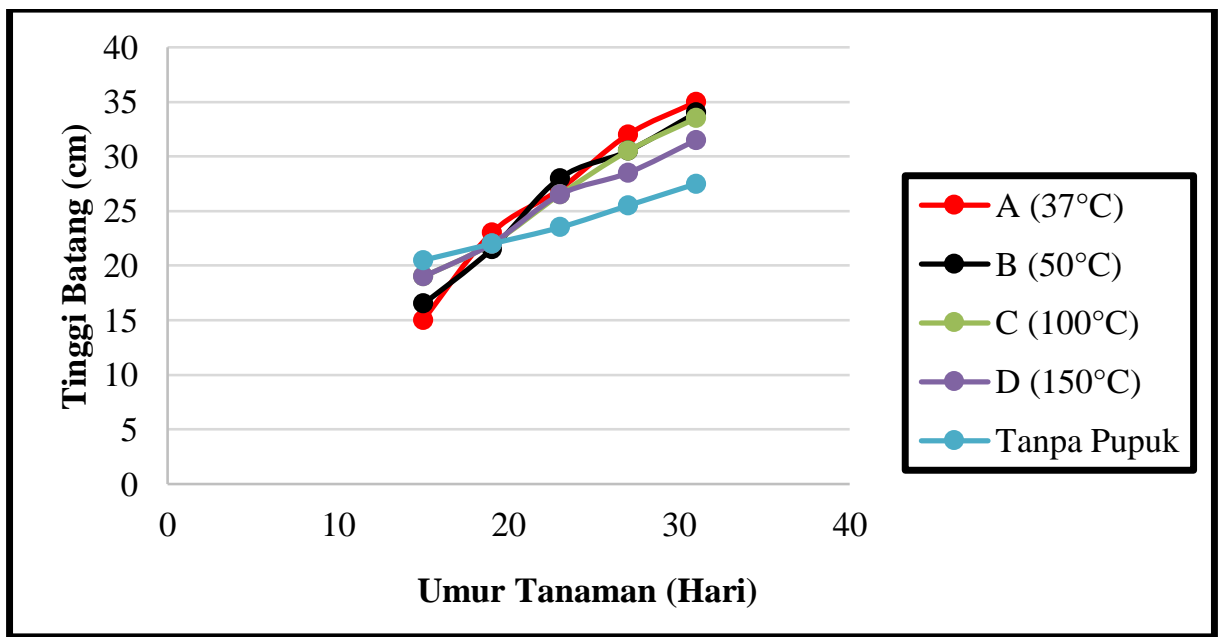

Gambar 2. Grafik pertumbuhan panjang batang tanaman kacang tanah

Gambar 2 menunjukkan pertumbuhan tinggi batang kacang tanah selama interval waktu 31 hari lebih cepat pertambahan pertumbuhan dari awal pemupukan sampai akhir suhu pada suhu $37^{\circ} \mathrm{C}, 50^{\circ} \mathrm{C}$ dan suhu $100^{\circ} \mathrm{C}$ mengalami pertumbuhan yang cepat. Hal ini dikarenakan pupuk yang dikeringkan dengan suhu rendah menyebabkan kandungan kalsium pada cangkang telur tidak berkurang, sehingga kandungan kalsium pada cangkang tersebut dapat membantu proses pertumbuhan kacang tanah.

Tabel 5. Hasil pengamatan jumlah tangkai pada pertumbuhan kacang tanah

\begin{tabular}{ccccccc}
\hline \multirow{2}{*}{ No Umur Tanaman (Hari) } & \multicolumn{5}{c}{ Jumlah Tangkai Tanaman } \\
\cline { 3 - 7 } & & A & B & C & D & Tanpa Pupuk \\
\hline 1 & 11 & 4 & 4 & 3 & 4 & 4 \\
2 & 15 & 7 & 6 & 5 & 6 & 5 \\
3 & 19 & 7 & 6 & 6 & 6 & 6 \\
4 & 23 & 7 & 7 & 7 & 7 & 6 \\
5 & 27 & 7 & 7 & 7 & 7 & 6 \\
6 & 31 & 8 & 8 & 7 & 7 & 6 \\
\hline
\end{tabular}


Tabel 5 menunjukkan pertumbuhan jumlah tangkai pada tanaman kacang tanah, pada hari ke 31 dengan suhu $100^{\circ} \mathrm{C}$ dan $150^{\circ} \mathrm{C}$ interval pertumbuhan tangkainya hampir sama. Namun pada suhu $37^{\circ} \mathrm{C}$ dan suhu $50^{\circ} \mathrm{C}$ pertumbuhan tanaman berupa pertambahan jumlah tangkai lebih cepat.

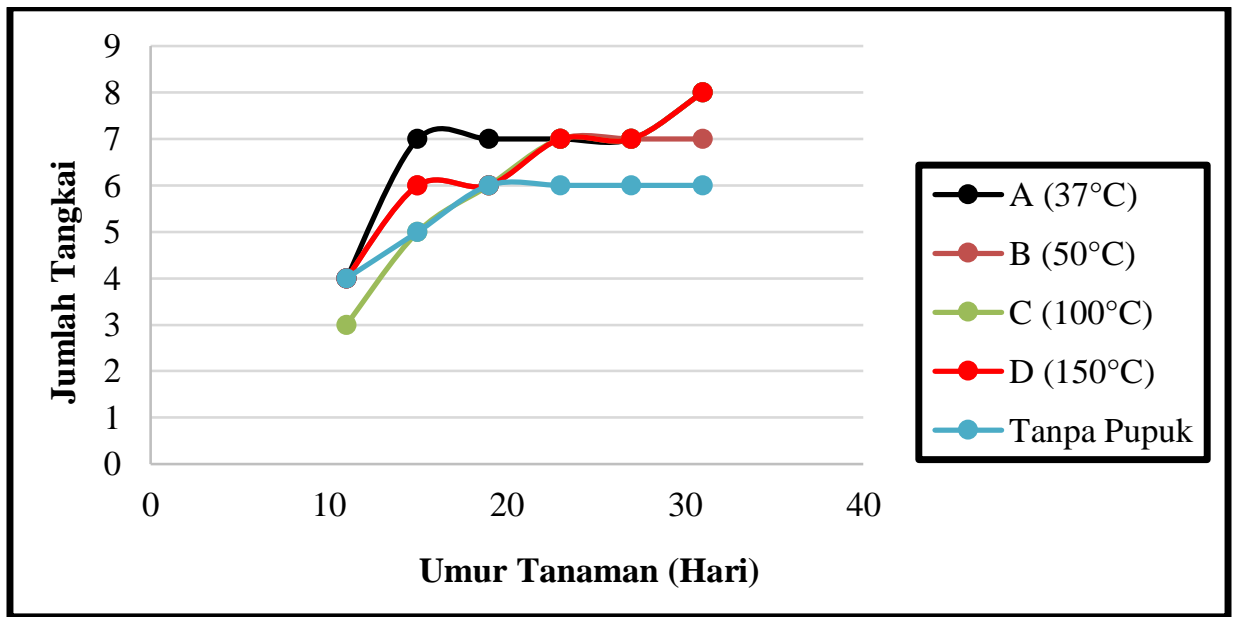

Gambar 3. Grafik jumlah tangkai pada tanaman kacang tanah

Pada Gambar 3 dapat dilihat pertumbuhan tanaman dengan jumlah tangkai dari umur 11 hari hingga 31 hari pertambahan jumlah tangkai antara tanaman dengan suhu $37^{\circ} \mathrm{C}$ dan suhu $50^{\circ} \mathrm{C}$ jumlah tangkainya hampir sama, hal ini mungkin dikarenakan adanya kandungan unsur atau senyawa lain yang terdapat dalam pupuk cangkang telur selain kalsium yang dapat memengaruhi perkembangan tanaman.

Tabel 6. Hasil pengamatan jumlah daun pada pertumbuhan kacang tanah

\begin{tabular}{ccccccc}
\hline No & $\begin{array}{c}\text { Umur Tanaman } \\
\text { (Hari) }\end{array}$ & A & B & Jumlah Daun Tanaman & D & Tanpa Pupuk \\
\hline 1 & 11 & 16 & 16 & 14 & 14 & 16 \\
2 & 15 & 24 & 24 & 18 & 22 & 20 \\
3 & 19 & 28 & 24 & 24 & 24 & 24 \\
4 & 23 & 28 & 28 & 26 & 28 & 24 \\
5 & 27 & 28 & 28 & 28 & 30 & 24 \\
6 & 31 & 32 & 28 & 32 & 32 & 24 \\
\hline
\end{tabular}

Pertumbuhan tanaman dengan jumlah daun dapat dilihat pada Tabel 6 pada pertumbuhan tersebut hampir semua sama dengan pertambahan jumlah daun dari umur 11 hari sampai 31 hari. Hal ini biasa terjadi pada proses pertumbuhan tanaman, tidak hanya kalsium saja yang dapat memengaruhi pertumbuhan tanaman, namun beberapa unsur lainnya yang terkandung pada pupuk cangkang telur. Grafik pertumbuhan daun pada tanaman kacang tanah ditunjukkan pada Gambar 4. 


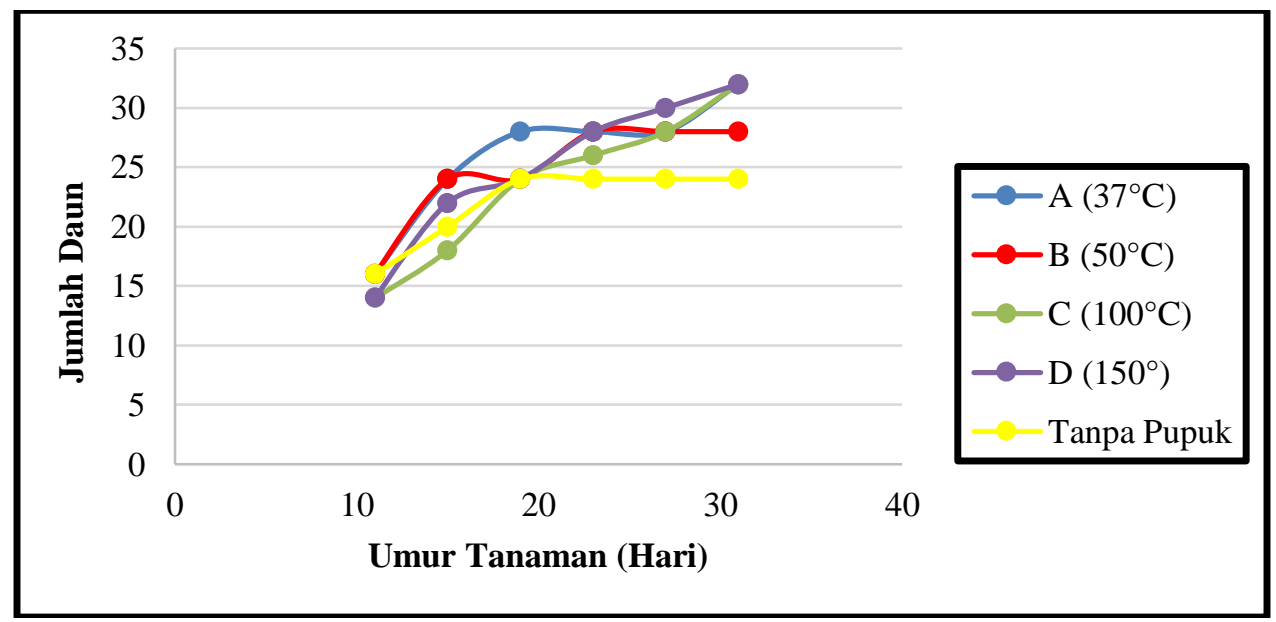

Gambar 4. Grafik jumlah daun pada tanaman kacang tanah

Hasil yang ditunjukkan pada Gambar 4. dapat diketahui bahwa tanaman memerlukan unsur hara yang tidak hanya berupa kalsium, melainkan tanaman juga memerlukan unsur hara lain berupa Fospor $(\mathrm{P})$, magnesium $(\mathrm{Mg})$, Kalium $(\mathrm{K})$, Nitrogen (N) yang dapat membantu proses pertumbuhan tanaman dengan baik.

\section{KESIMPULAN}

Pengaruh suhu pengeringan terhadap kualitas pupuk cangkang telur menunjukkan bahwa suhu sangat berpengaruh pada kualitas pupuk cangkang telur. Penggunaan suhu yang sangat tinggi dengan waktu pengeringan yang cukup lama dapat mengurangi nilai kadar kalsium yang terkandung dalam cangkang telur. Dalam hasil penelitian suhu yang baik digunakan dalam proses pengeringan cangkang telur ayam yaitu suhu $37^{\circ} \mathrm{C}, 50^{\circ} \mathrm{C}$ dan suhu $100^{\circ} \mathrm{C}$. Hasil pengujian nilai kadar kalsium diperoleh suhu $37^{\circ} \mathrm{C}$ sebesar $1,32 \%$, suhu $50^{\circ} \mathrm{C}$ sebesar $1,06 \%$, suhu $100^{\circ} \mathrm{C}$ sebesar $2,21 \%$ dan suhu $150^{\circ} \mathrm{C}$ sebesar $0,80 \%$.

\section{DAFTAR PUSTAKA}

Asip, F., R. Mardhiah., \& Husna. (2008). Uji efektivitas cangkang telur dalam mengadsorbsi ion Fe dengan proses batch. Jurnal Teknik Kimia, 15(2), 22-26.

Aslawati. (2011). Aplikasi Pupuk Cair Dari Cangkang Telur Dengan Aktifator Mikroorganisme Lokal terhadap Pertumbuhan Bibit Tanaman Kakao. [Skripsi]. Samarinda: Program Studi Budidaya Tanaman Perkebunan Politeknik Pertanian Negeri Samarinda.

Cibro MA. (2008). Respon Beberapa Varietas Kacang Tanah (Arachis hypogaea L.) terhadap Pemakaian Mikoriza Pada Berbagai Cara Pengolahan Tanah. [Tesis]. Medan: Univeristas Sumatera Utara.

Ganjar, I.G \& A. Rohman. (2007). Kimia Farmasi Analisis. Yogyakarta: Pustaka Belajar.

Giancoli. (2001). Fisika Edisi Kelima Jilid 1. Jakarta: Erlangga.

Harrison. (2000). Preserving Food Drying Fruit and Vegetable. Georgia: University of Geordgia.

Nurhidayati et al. (2008). Pembuatan Pupuk Kompos Dari Bahan Jerami Padi Bagi Tumbuhan Bayam. Palembang: Universitas Sriwijaya.

Nurjanah, R. Susanti., \& K. Nazip(2017). Pengaruh Pemberian Tepung Cangkang Telur Ayam (Gallus gallus) terhadap Pertumbuhan Tanaman Caisin (Brassica juncea L.) dan sumbangannya pada Pembelajaran Biologi SMA. Prosiding Seminar Nasional Pendidikan IPA 2017, 515-528.

Prsetyaningrum, A. (2010). Rancang bangun oven drying vaccum dan aplikasinya sebagai alat pengering pada suhu rendah. Riptek, 4(1), 45-53.

Rahmi, Y., B.A.S. Santosa., \& S. Widowati. (2015). Teknologi pengolahan produk olahan kacang tanah. Monograf Balitkabi, 13, 376-393.

Rahmianna A.A., H. Pratiwi., \& D. Harnowo. (2015). Budidaya kacang tanah. Monograf Balitkabi, 13, 133169.

Riansyah, A., A. Supriadi., \& R. Nopianti. (2013). Pengaruh perbedaan suhu dan waktu pengeringan terhadap karakteristik ikan asin sepat siam dengan menggunakan oven. Jurnal Fistech, 2(1), 53-68. 
Solpiati. (2013). Pemberian Pupuk Organik Cair NASA terhadap Pertumbuhan Tanaman Buah Naga Super Red. [Karya Ilmiah]. Samarinda: Politeknik Pertanian Negeri Samarinda.

Widyanti, E., E. Kusumawati., A.F. Sukmana., \& Z.M.A. Mudzakkir. (2019). Penentuan Tekanan dan Waktu Optimum Dalam Pembuatan Serbuk Telur Menggunakan Oven Vakum. Fluida: Jurnal Sains dan Teknologi, 12(2), 50-57.

Zulti, F. (2008). Spektroskopi Inframerah, Serapan Atomik, Serapan Sinar Tampak, dan Ultraviolet Hidrokisapatit Cangkang Telur. [Skripsi]. Bogor: Institut Pertanian Bogor. 